\begin{tabular}{|c|c|c|c|}
\hline 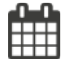 & Received 29/07/2019 & $\sqrt{E \mathbb{E}}$ & Published 14/10/2019 \\
\hline
\end{tabular}

\title{
The Cross Ethnic Relationships in Strengthening Social Cohesion in Malaysia
}

\author{
${ }^{1}$ Hairol Anuar Mak Din, ${ }^{2}$ Nor Azlili Hassan, ${ }^{3}$ Mansor Mohd Noor \\ E-mail: hairolanuar@kuis.edu.my', azlili@utar.edu.my², mansormohdnoor@yahoo.com ${ }^{3}$ \\ ${ }^{1}$ Senior Lecturer, Kolej Universiti Islam Selangor, Malaysia \\ ${ }^{2}$ Assistant Professor, Universiti Tunku Abdul Rahman, Malaysia \\ ${ }^{3}$ Principal Research Fellow, Institute of Ethnic Studies, Universiti Kebangsaan Malaysia, Malaysia
}

ABSTRACT
The foundation of developing a nation in Malaysia is based on the Keywords
integration by which each ethnic identity is maintained and preserved
within the Malaysian Federal Constitution. However, there is always a Cross ethnic
negative perception of the "outsider" on the harmonious condition in
Malaysia. This is because they are only influenced by the "talk conflicts" social cohesion;
that spreading in the social media as if tomorrow will recur the bloody individual;
tragedy of May 13, 1969. Yet, the Institute of Ethnic Studies, Universiti
Kebangsaan Malaysia has clarified that Malaysia is now in the era of
social cohesion. In this era, the behavior of Malaysians is at the 'everyday-
defined' level, where 'they talk conflict, they walk cohesion' and this is
healthy psychosocial behavior. Hence, in exploring the strengthening level
of social cohesion, a survey was conducted on 554-business community
from various ethnic groups who had a direct connection to cross-ethnic
relationships. The objective of this study is to explore the dimensions of
cross-ethnic relationships experienced by the business community from
various ethnic groups and to study the impacts of cross-ethnic links on
social cohesion in Malaysia. This article is a sub-topic from a study on
social mobility among the Malaysian business community by specifying on
cross-ethnic relationships. There are three levels of ethnic relationships,
namely; at the individual level, community level and institutional level. The
findings found that the cross-ethnic relationships among the business
community in Malaysia is positive and significant in strengthening the
social cohesion in Malaysia.

\section{INTRODUCTION}

Malaysia, due to its geographical position has long been a strategic meeting place between the East and the West. Malaysia is the meeting place of great civilization of India and China and a place where significant religions of the world meet. The development of Malaysia as a multiracial nation is closely linked to the stated situation. People of different nationalities and backgrounds came and, many eventually settled down in the various states in Malaysia, giving rise to the ethnic variety of today. The presence of large numbers of Chinese and Indians is due to the colonial 'divide and rule' policy during the 19th century, when the British needed labor for economic exploitation of the Malay states. There was 
massive immigration of the Chinese and Indians during this period and, unfortunately, also gave rise to the ethnic problem in Malaysia. Before independence, the ethnic relationship of Malaysians fitted well into the attributes of plural societies. The economic condition of the various ethnic groups in Malaysia, under the 'divide and rule' policy, was for the benefit of the colonizer. The colonist manipulated the ethnic situation such that the various ethnic groups occasionally had any opportunity for interaction. They also started stereotyping one another, such as determining the field of work, Malays as farmers, Chinese as entrepreneurs, and Indians as laborers. This was the ethnic situation of the Malays, Chinese and Indians in Malaysia.

Ethnicity remains the most effective force in Malaysia even if its influence has been somewhat polluted by other social stratification forces, class, and gender. The effectiveness of ethnicity lies in its ability to combine both affective and instrumental appeals. As members of distinct and self-conscious cultural communities, Malays, Chinese, and Indians naturally were inclined to identify their respective languages, cultures, and religions, and thus actively struggled to preserve and disseminate them. Since they share common symbols and values, the ethnic members would primarily socialize and associate with their own. Thus, ethnicity continues to constitute an integral constituent of the individual Malaysia spirit and ethnic membership critically establishes his or her social life and taste. It follows that the effectiveness of affective appeals originates from the evident passionate attachments to a particular ethnicity that continues to influence individual identification and pattern of social life.

Malaysia is a country that consists of many ethnics, cultures, ways of life and histories (Majzub et. al 2011). The national education system in every country is closely related to the needs of the community as the symbiotic relationship exists between education and society. The education system should not ignore the political, economic and cultural ideologies that shape their environment. Since independence, one of the visions in Malaysia is to achieve national unity. Therefore, all educational policies have outlined unity as the most important objective to be achieved (Mustapha et. al 2009). The Razak Report 1956 served as the basic formation of a national education-related policy such as the Rahman Talib Report. The education system in Malaysia reflects the diversity of cultures and languages, especially at primary levels. Under the Education Act 1961 and Education Act 1996, there are several streams using different rules across the primary, secondary, and university levels (Government Transformation Program 2010). Students can learn their native languages, while the same curriculum and syllabus are used to form the nation's identity and spirit of patriotism. Besides, the Malay Language is made compulsory in all National-type Schools (Chinese) and National-type Schools (Tamil), while English is mandatory for all types of schools. At the secondary level, most students from National Schools and National-type Schools will further their studies to National Secondary Schools. However, there is also attraction among the students to study in Islamic religious schools. Various types of primary schools enable to transfer the three major languages and cultures in Malaysia even though the students from 
different ethnic groups remain separated and isolated until they join the secondary schools and higher institutions (Government Transformation Program 2010).

In Malaysia, the government has implemented many approaches to promote national unity and patriotism among different ethnic groups in Malaysia (Majzub et. al 2011). However, there are still racial issues exist among the community that may threaten national unity and harmony among the ethnics (Majzub et. al 2011). Each ethnic group will protect their rights and privileges, thus creating a social boundary. These boundaries can lead to ethnic tensions and conflicts between ethnic groups (Mustapha et. al 2009). Hence, it is essential to emphasize the value of racial diversity and national unity to all members of society. Individuals from various ethnic backgrounds should know and appreciate the attitudes, institutions, and traditions shared by all Malaysians (Hamdan et. al 2010). To note, cohesion is the degree to which group members come together as one unit to reach a common goal. Members of cohesive groups see themselves as one entity rather than a collection of individuals. Group members have positive regard for one another and get along well. They listen to and trust one another as well as respect each other's opinions even if they disagree. It is a feeling of deep loyalty and togetherness and includes the degree to which each individual has made the group's goal his or her own. The productivity of groups is strongly related to their cohesiveness. Research has shown that cohesive groups perform better than non-cohesive groups in decision-making activities.

Furthermore, the world was shaken by the Christchurch mosque shootings tragedy at a mosque in Christchurch, New Zealand, during Friday prayer on 15 March 2019. The attacks killed and injured many people. To note, New Zealand is the second safest country in the world, and the ranking of the global security index is in a low position, which is 1,241 in 2017 . The tragedy has recapped on the same incident that happened on April 9, 2017 where several churches in Egypt were attacked that resulted in many people were killed and forced the government to declare an emergency. This tragedy showed the world community about the humanitarian conflicts between the different ethnic and religious groups, and have raised concerns among the international community.

The ethnic conflicts may also happen among the business community. The success or failure of a business community in entrepreneurship is dependent on their innovative behavior in fostering social relationships with their families, business partners, employees, customers, and suppliers who will give benefit to them, both in material and non-material. Social relationships can be formed through face-toface or online interactions. The use of internet revolution has a significant impact on everyday life especially in entrepreneurship around the world. Today, there are numbers of men and women in Malaysia who have participated in business area. The successful of participation in business depends on a number of things other than money as the capital, infrastructure and availability of goods and services. The most important thing is the non-material element including innovative behavior that aims to create the business networks with various ethnic groups including family members, friends, customers, agents, suppliers and competitors as well as other business communities. 
To note, an individual feels a sense of personal deprivation when one is receiving less than what one desires and deserves. In Malaysia, the economic inequality between the ethnic groups and the prevalence of ethnic stratification and mobilization transformed the personal sense of deprivation into an ethnic collective sense of relative deprivation. Moreover, this economic deprivation was circumscribed by the prevailing discourse that perceived and constructed inequality in the society in predominantly ethnic terms. Hence, Malays routinely compare what they have, what they think they deserve or are entitled to with the other ethnic groups, particularly the Chinese. Accordingly, the Malay-dominated state classified and presented the official data on income and employment patterns in the society in primarily ethnic categories.

There are a few research materials and discussions on business communities among various ethnic groups in Malaysia (Kasuma, 2017). This paper will examine the cross-ethnic relationships and social cohesion among the business community of different ethnic groups in Malaysia. Therefore, the purpose of this paper is first, to explore the dimensions of cross-ethnic relationships experienced by the business community from various ethnic groups; and, secondly, to study the impacts of cross-ethnic relations towards social cohesion in Malaysia. Therefore, the following research questions will be answered: What are the dimensions of cross-ethnic relationships experienced by the business community of different ethnic groups? What are the impacts of cross-ethnic relations on social cohesion in Malaysia?

Empirical studies on the business community and social cohesion in Malaysia are still very few, as most studies focus on the basic aspects of identifying entrepreneurs such as the study on entrepreneurial and their characteristics. The economic development of a country depends on the progress shown by a business unit within the country. Businesses should show their progress through performance or growth that definitely requires a high commitment by its business community. The impact of national economic development needs to be seen in improving business performance or growth.

In the Global Peace Index (GPI) 2018 report released on June 6, Malaysia has improved its ranking in the 25th as the safest country in the world. The demographics in Malaysia consists of 40 ethnic groups and 216 ethnic tribes with multiple religious beliefs and different languages as well as cultural groups. This composition can be well maintained in line with the Quranic verses in Surah Al-Hujarat (13); 'O People! Lo! We created you from a man and a woman and made you nations and tribes, that ye may know one another.

The history of Malaysia after independence until 2018 has shown that there are only three significant ethnic conflicts happened namely, May 13th 1969, Rawa Village 1998, and Kampung Medan 2001 tragedy. However, according to Khairol Anuar (2014), these cases are only limited and isolated in certain areas around Kuala Lumpur and Penang. The success of the government in maintaining a peaceful society in Malaysia has been recognized by the world. This has been documented in the 2009 Global Smart Partnership Dialogue which recommends all African countries facing ethnic conflict to emulate Malaysia's achievement in managing ethnic diversity (Utusan Malaysia, 2009). The current peaceful 
status of the country is also recognized by the Japanese Crown Prince, Naruhito during his five-day official visit to Malaysia with the expectation that Japan can learn many things about the plural society as Malaysia which represents a variety of cultures and religions, but can live together harmoniously (Bernama, April 13, 2017).

Social ties are essential assets for the business community. Baker (1990); Gulati (1995) and Gulati and Martin (1999) revealed that the social relationships create opportunities to identify new business ideas, new products, and new markets as well as inspire business community to take risks and innovate, and develop business success under the settings of uncertainty. These ties also provide benefits such as joint problem solving, information exchanging and resource sharing to actors in the networks as studied by Uzzi (1996). These resources include not only finance and other material resources but also information, ideas, advice, and customers. The resources are usually obtained through the business community's personal network. In this aspect, a social network provides the business community with information, support, contact, and credibility.

Also, studies have shown that the positive relationships between individuals from different ethnic groups can lead to a reduction of prejudice (Molina et al., 2006), improving the sense of belonging (Nier et al., 2001) and interpersonal relationships (Tropp 2007). In a study that examines the relationship between ethnic groups, it was found that Koreans who live in China and have their social interactions with the Chinese community have low levels of ethnic identity due to the discrimination that often occurred among them (Lee et al., 2007). Based on the context of the relationship between ethnic groups in Malaysia, the ethnic relations are very complex, complicated and sensitive, especially when it comes to religious, cultural and linguistic issues that play important features in identity based on the phenomena that the British have formed in the context of colonization (Shamsul Amri Baharuddin 2008). The dynamic relationship between each ethnic group determines the changes in the building of the identity and way of life of an individual living in multicultural society and how they receive each other in the context of social and cultural etiquette perspective (Filpisan et al., 2011). When an individual has an interaction, he cannot ignore the members in his group, which is, in particular, distinctive and unique to the culture of his own ethnic group, but also a common characteristic of the ethnic group (Filpisan et al., 2011).

Shamsul Amri Baharuddin (2011) and Pue Giok Hun (2013) stressed that the formula of Malaysia's success in dealing with various challenges in managing ethnic diversity in the country is not derived or emerged naturally but is the result of ongoing bargainings and negotiations in treating differences and similarities of each ethnic groups. Among the processes that bind the relationships between ethics in this country is the emergence of 'cross-ethnic relationships' that rooted and widespread in Malaysia. This practice is in line with Eriksen's view (2002), that stated when cultural differences usually highlight their disparities in social relationships between members of different ethnic groups, then those social relationships have elements of ethnicities. In other words, two individuals from different 
ethnic groups can build nonracial relationships when their behavior is not motivated by racism. Cox (1948) stressed that relationship behavior can be defined based on the role of works and ethics of the profession rather than based on race or ethnicity.

When individuals see each other's relationships as playing their roles, this can lead to strategies in reducing racial and ethnic awareness (Banton 1991). To see the ethnic and racial relationships, Barth (1969) recommended that focus should be given not only to see the historical characteristics of ethnic group formation but to examine the different processes that occur in the process of forming, reducing or maintaining ethnic groups. Social relationships are an important asset to the business community. Baker (1990), Gulati (1995) as well as Gulati and Martin (1999) revealed that social relationships create opportunities to identify new business ideas, products, and markets as well as encourage the business community to take risks and innovate, especially when dealing with unexpected situation. This relationship also benefits in the problem solving, information exchange and resource sharing to the perpetrators in business networks as analyzed by Uzzi (1996). These resources include not only financial and other material resources but also information, ideas, advice, and customers. These resources are usually obtained through a private network of business communities. In this aspect, social networks provide information, support, relationships, and credibility to the business community.

Several researchers have analyzed entrepreneurial issues, new business development, and small business progress. The main argument for most of these studies is that a new entrepreneur or small business community does not have enough experience and resources. The business community collects the necessary resources through their personal network to run their business. However, there are only a few studies that have been discussing about cross-ethnic relationships among business communities that affect social cohesion in Malaysia. This study is interested in studying cross-ethnic relationship as it is said that a different businessman or entrepreneur encounters different dimensions in his business relationship which then give impacts on social cohesion. Hence this study is significant, especially in reviewing cross-ethnic relationships among Malaysian society as a whole.

This study sought to fill the research gap on the absence of empirical evidence about the crossethnic relationships in strengthening social cohesion among business communities of various ethnic groups in Malaysia. By so doing, the study makes a contribution to the existing body of knowledge on business community performance and strategies in the context of a developing country.

To see whether the lives of Malaysians are moving towards 'ethnic group unity' or continuously 'raising ethnic differences', this study is carried out by applying 'box and boundary' concepts in terms of 'thickening or thinning' relationships between one ethnic group and another. This study focuses on the cross ethnic relationship and social cohesion which emphasizes on the cross ethnic relationships at three levels, namely individuals, communities and institutions.

The research design was descriptive by using the questionnaires as the research methodology. A total of 554 respondents consisting of the business community of different ethnic groups, namely Malays, 
Chinese and Indians. The sample selection is using purposive sampling technique with sample determination based on Krejie \& Morgan sample determinant table. The findings was analyzed based on correlation method by using SPSS program.

\section{DISCUSSION}

The discussions in this study are projected at cross ethnic relationships that bind ethnic relations in Malaysia and make the relationships so dynamic. There are three levels of relationships, namely; at the individual level, community level and institutional level.

\section{Individual Level}

The overall findings revealed that cross-ethnic relationships at the individual level are constructed among the Indian and Malay respondents than the Chinese and Bumiputra respondents. Relatively, the Indian respondents emphasized social relationships at an individual level compared to the respondents from other ethnic groups, while the Bumiputra showed a low gap.

Table 1: Individual Level

\begin{tabular}{|c|c|c|c|c|c|}
\hline \multicolumn{6}{|c|}{ Individual Level } \\
\hline \multicolumn{6}{|c|}{ Dimension: Agree/ Positive } \\
\hline Chatting & $90.6 \%$ & I-100\% & M-93.2\% & C- $90 \%$ & B-78.9\% \\
\hline $\begin{array}{l}\text { Visitting friends of } \\
\text { different ethnics who } \\
\text { experienced a tragedy }\end{array}$ & $86 \%$ & I-90.9\% & M-89.2\% & B- $80 \%$ & C- $-74.2 \%$ \\
\hline $\begin{array}{l}\text { Outing for eat with } \\
\text { friends of different } \\
\text { ethnics }\end{array}$ & $80.6 \%$ & $\mathrm{I}-95.5 \%$ & M-82.6\% & C- $77.4 \%$ & B-71.6\% \\
\hline $\begin{array}{l}\text { Employer and } \\
\text { employees are working } \\
\text { together }\end{array}$ & $79.1 \%$ & $\mathrm{I}-90.9 \%$ & M-89.2\% & B- $80 \%$ & C-74.2\% \\
\hline $\begin{array}{lll}\text { Inviting friends } & \text { of } \\
\text { different ethnics } & \text { in } \\
\text { social activity } & \end{array}$ & $77.7 \%$ & $\mathrm{I}-95.5 \%$ & M-79.1\% & C-72.6\% & B-71.6\% \\
\hline
\end{tabular}

Based on Table 1, the findings indicated that chatting activity is the highest and positive dimension compared to other items at the personal level, which is $90.6 \%$. This was followed by visiting friends of different ethnic groups who have experienced a tragedy (86\%) and out to eat with friends of different ethnic groups (80.6\%). Then, the dimensions of positive responses at the fourth and fifth levels were in the item of employer and employee working together (79.1\%) and inviting friends of different ethnic groups to join in social activity $(77.7 \%)$.

The cross-ethnic relationship at the workplace in the individual level shown that the Indian, Malay and Chinese ethnic groups recorded a high percentage of $100 \%, 93.2 \%$, and $90 \%$. Chatting activity is a 
common behavior among the Malaysian community. Typically in business, friendliness through conversation is a strategy to attract the customers and being practiced by all ethnic groups.

Visiting friends from other ethnic groups who are experienced by a tragedy is the second highest item at the individual level in the business workplace. The Indian community (90.9\%), Malays (89.2\%) and Bumiputera (80\%) are well acquainted with the welfare of business associates of other ethnic groups. This shows that the sense of responsibility and sympathy are the sharing value that goes beyond the racial boundaries.

Outing for eat with friends from other ethnic groups is also agreed among the respondents. Although there are different ethnic backgrounds such as different beliefs and religions, it is not a barrier for the Indians (95.5\%), Malays (82.6\%) Chinese $(77.4 \%)$ and Bumiputra $(71.6 \%)$ to go for outing together. There are some Chinese and Bumiputra foods that can not be eaten by the Malays, but the findings stated that the four ethnic groups are comfortable to go for outing together.

\section{Community Level}

Overall, the study found that cross-ethnic relationships at the community level are built up for Indian and Malay respondents compared to Chinese and Bumiputera respondents. However, the percentage difference of both respondents is small. Relatively, the Bumiputra respondents showed an improvement in social relations at community level rather than individual level.

Table 2: Community Level

\begin{tabular}{|c|c|c|c|c|c|}
\hline \multicolumn{6}{|c|}{ Community Level } \\
\hline \multicolumn{6}{|c|}{ Dimension: Agree / Positive } \\
\hline $\begin{array}{l}\text { Festivals increase } \\
\text { business profit }\end{array}$ & $86.5 \%$ & $\mathrm{I}-100 \%$ & C- $90.2 \%$ & B-86\% & M-85.2\% \\
\hline $\begin{array}{l}\text { Religion is well } \\
\text { practiced }\end{array}$ & $85.8 \%$ & $\mathrm{I}-100 \%$ & M-86.8\% & C- $85.5 \%$ & B- $78.7 \%$ \\
\hline $\begin{array}{l}\text { Satisfied with daily life } \\
\text { among various ethnics }\end{array}$ & $83.6 \%$ & $\mathrm{I}-95.5 \%$ & M-84.1\% & $\mathrm{C}-82.3 \%$ & B-79.8\% \\
\hline Business operated well & $82.5 \%$ & I-95.5\% & C-87.1\% & B-81.9\% & M-81.1\% \\
\hline $\begin{array}{l}\text { Public facility shared } \\
\text { together }\end{array}$ & $82.3 \%$ & $\mathrm{I}-86.4 \%$ & M-84.6\% & B-76.6\% & $\mathrm{C}-75.8 \%$ \\
\hline
\end{tabular}

Note: I(Indian), M (Malay), C (Chinese), B (Bumiputra)

As shown in Table 2, the highest percentage (86.5\%) at the community level which falls within the highest or positive response is that the festivals will increase the business profit. This is followed by religious practices that are well implemented $(85.8 \%)$. The third highest item at the community level is on the satisfaction with daily life among the multi-ethnic community (83.6\%). The fourth (82.5\%) and the fifth $(82.3 \%)$ highest are on the items where the business activity is well operated and public facilities are used together. The findings also found that the festivals would increase business profit to be the highest percentage among all ethnic groups at the community level, which includes $100 \%$ for the Indians, $90.2 \%$ for the Chinese, $86 \%$ for the Bumiputras and $85.2 \%$ for the Malays. This is because the plurality of 
Malaysian community has made the festivals are celebrated throughout the year. The need for the celebrations has increased the business profit of the business community. Thus, the four ethnic groups agreed on this item.

The racial harmony in Malaysia is a result of high tolerance among religious communities that representing certain ethnic groups. The findings revealed that the religious practices in this country can be performed harmoniously. It is supported by a very good percentage from the Indian (100\%), Malays $(86.8 \%)$, Chinese $(85.5 \%)$ and Bumiputra $(78.7 \%)$. The study indicated that the level of living satisfaction among the multi-ethnic communities is extremely high, which is Indian (95.5\%), Malays (84.1\%), Chinese $(82.3 \%)$ and Bumiputeras (79.8\%). The diversity of ethnics is practiced in everyday life in Malaysia whether it is official or nonofficial. Finally, the business activity is well operated and the public utilities are enjoyed together among the various ethnic groups at the community level. The study found that the dimensions of positive responses and agreed on both items including among the Indians $(95.5 \%$ and $86.4 \%)$, Chinese (87.1\% and $75.8 \%)$, Bumiputera (81.9\% and $76.6 \%)$ and Malays $(81.1 \% 75.8 \%)$.

\section{Institutional Level}

\section{a. Characteristics of multiethnic membership}

The overall findings stated that cross-ethnic relationships at the institutional level from a multiethnic membership perspective showed that the majority of responses are over $80 \%$ for all ethnic groups. Majority ethnic groups have a high percentage of involvement in the characteristics of multi-ethnic membership.

Table 3 Institutional Level: Characteristics of Multiethnic Membership

\begin{tabular}{lccccc}
\hline \multicolumn{5}{c}{ Institutional Level } \\
\hline Characteristics of Multiethnic Membership \\
(Highest) \\
Sports and Recreation & $\mathbf{8 7 . 1 \%}$ & I-100\% & B-89.4\% & M-86.3\% & C-84\% \\
Club & & & & \\
Consumer Club & $\mathbf{8 6 . 3 \%}$ & B-90.9\% & M-86.3\% & C-80.8\% & I-70\% \\
Environmental Club & $\mathbf{8 5 . 2 \%}$ & I- $100 \%$ & B-86.2\% & M-84.6\% & C-81\% \\
Rakan Cop & $\mathbf{8 4 . 6 \%}$ & I- $100 \%$ & C-92.3\% & B-88\% & M-82.2\% \\
Business Club (State) & $\mathbf{8 2 . 7 \%}$ & I- $100 \%$ & B-84.4\% & M-81.8\% & C-80.5\% \\
\hline
\end{tabular}

Note: I(Indian), M (Malay), C (Chinese), B (Bumiputra)

Based on Table 3, the findings showed there was the highest percentage at the institutional level in the characteristics of multi-ethnic membership, including Sports and Recreation Club (87.1\%), Consumer Club (86.3\%) and Environmental Club (85.2\%). Rakan Cop earned a percentage of $84.6 \%$ and a total of $82.7 \%$ for the item of the Business Club. The Sports and Recreational Club is the highest club participated, which is Indians (100\%), Bumiputra (89.4\%), Malays (86.3\%) and Chinese (80.5\%). This is because sports and recreational clubs are the activities that go beyond the ethnic boundaries and are participated by those who shared the same interests. 
Consumer Club is the second-highest club to be interested among different ethnic groups such as Bumiputra (90.9\%), Malays (86.3\%), Chinese $(80.8 \%)$, and Indians $(70 \%)$. Consumerism issues are important as they are related to individual rights as the consumers and this club are not limited to certain ethnics only. The study also showed that the Environmental Club and Rakan Cop are participated by various ethnic groups. The Consumer Club and Environmental Club are the clubs that struggle for individual rights and responsibilities. The questions and issues on the environment as well as public security are considered as the primary consideration by all ethnic groups, which is Indian (100\%), Bumiputra (86.2\% and $88 \%$ ), Malays ( $84.6 \%$ and $81.8 \%$ ) and Chinese ( $81 \%$ and $92.3 \%)$.

At the institutional level, the membership in the Business Club is comprised of four ethnic groups, namely Indians (100\%), Bumiputra (84.4\%), Malays (81.8\%) and Chinese (80.5\%). As the business community, it is vital for the respondents to participate in the Business Club, at the state level, to create their business networks and obtain information from the authorities.

\section{b. Characteristics of similar ethnic membership}

The findings indicated that cross ethnic relationships at the institutional level from the perspective of the characteristics of the similar ethnic membership showed inconsistent percentages. The gap between groups on the characteristics of the similar ethnic membership is large for the two highest clubs $(80.1 \%$ and $76.5 \%)$ compared to the other three clubs $(36.3 \%, 33.9 \%$ and $30.6 \%)$.

Table 4 Institutional Level: Characteristics of same ethnic membership

\begin{tabular}{lccccc}
\hline \multicolumn{7}{c}{ Institutional Level } \\
\hline \multicolumn{7}{c}{$\begin{array}{c}\text { Characteristics of same ethnic membership } \\
\text { (Highest) }\end{array}$} \\
Death Welfare Club & $\mathbf{8 0 . 1 \%}$ & M-84.8\% & I-77.8\% & C-75.7\% & B-65.9\% \\
Religious Club & $\mathbf{7 6 . 5 \%}$ & I-94.4\% & M-81.3\% & C-79.5\% & B-52.4\% \\
Political Parties & $\mathbf{3 6 . 3 \%}$ & I- $41.2 \%$ & C-40\% & M-37.1\% & B-30.7\% \\
Arts and Culture Club & $\mathbf{3 3 . 9 \%}$ & I- $55.6 \%$ & M-37.1\% & C-29.6\% & B-18.8\% \\
Martial Arts Club & $\mathbf{3 0 . 6 \%}$ & M-35.2\% & B-20.6\% & I-14.3\% & C-10\% \\
\hline
\end{tabular}

Note: I (Indian), M (Malays), C (Chinese), B (Bumiputra)

Table 4 shows that the highest percentage of the characteristics of similar ethnic membership is $80.1 \%$, which is held in the membership of the Death Welfare Club and followed by the membership in the Religious Club (76.5\%). The relatively balanced percentage of the similar ethnic membership was found in the political parties (36.3\%), Arts \& Culture Club (33.9\%) and Martial Arts Club (30.6\%).

Research findings on the characteristics of same ethnic membership at the institution's highest level can be divided into two parts, namely $50 \%$ and below $50 \%$. The two clubs with the highest ethnic membership are the Death Welfare Club and Religious Club. The names and the goals of the club have revealed the exclusivity of the club itself and found limited to religious restrictions, which is the Malays (84.8\% and $81.3 \%)$, Indians (77.8\% and 94.4\%), Chinese (75.7\% and 79.5\%) and Bumiputra $(65.9 \%$ and 52.4\%). The Political parties, Arts and Culture Club and Martial Arts Club also gained the highest 
percentage of the same ethnic membership. However, the percentage are relatively low as the current respondents of different ethnic groups are more open-minded.

In summary, the research findings showed that there is a significant and positive relationship between the cross-ethnic relationships and social cohesion among the Malays, Chinese, Indians and Bumiputra business communities. The respondents have a positive cross-ethnic relationships with their different business communities. The level of social cohesion among the business community is good. The results were to be positive and the respondents confirmed that the nature of their daily life will be always related and involved various ethnic groups including in the area of business competition. They are also found to be tolerance and caring on each other even though they are trying to gain benefits in their own business field.

The business community from various ethnic groups are always in contact with one another and participate in social dimensions in gaining social status in society (Mohd Noor 2012). Significantly, the Malaysians community seems to experience a rapid change along with the economic growth and modernization in the society.The situation creates individuals from different ethnic backgrounds to have mutual contact with each other and interdependence. Ethnic loyalty is assumed to be the factor in establishing relationships among various ethnic groups in Malaysia. In fact, the significant way to study ethnic relations is by focusing on the elements of relationships at individual level, community level and institutional level, in their pursuit of good and quality of life.

Thus, cross-ethnic relationships have a significant impact on social cohesion. This shows that the respondents are still able to do business through their relationships with other ethnic groups by making them their business partners. Good social relationships with other ethnic groups enable them to succeed in their business. The findings confirmed the importance of business networking for business performance and development. Duchesneau and Gartner (1988) also found that successful business communities were more active in their social relationships than unsuccessful businessmen. Moreover, successful businessmen spent more time in communicating with their business partners, customers, and other business communities. Hansen (1995) also found that there ware positive relationships between business networking (size of entrepreneurship, degrees, and frequency) with new organizational growth.

\section{CONCLUSION}

The ethnic relations in Malaysia have been remarkably stable and even congenial since the year 1990. The rapid economic growth has enabled the state to pursue its ethnic policy without unduly overstraining the non-Malays. In the cultural field, the state has relaxed its pro-Malay policy while allowing the Chinese culture more access and opportunity in the public space. In general, outright conflicts have been avoided because both the rival ethnic communities were willing to give concerns and the economic inequality gap has narrowed between the Malays, Chinese and Indians. Indeed, the ruling 
coalition party won an unparalleled victory at the polls in 1995, with substantial support from the Chinese community for the first time.

The first strategic challenge in Vision 2020 is to create a unified nation and Malaysia is found to have succeeded in maintaining its harmonious environment in the social life in line with the achievement of national development. The findings on cross-ethnic relationships at individual, community and institutional levels found that the overall cross-ethnic relationships among the Malaysian business community are positive and cross ethnic practices are a significant factor in strengthening the social cohesion in Malaysia. In fact, ethnic relationships in Malaysia have been relatively agreeable due to extremism and intolerance, factors that can undermine the stability of society, have been soundly contained in Malaysian society. Nevertheless, one must remember that when ethnic members are overwhelmed by a sudden wave of anxieties and frustrations, they could become inclined to extremists' furious. Then, the ethnic members become highly vulnerable to extremists' furious during periods of political, economic and cultural crises because crises would overwhelm a community with obsessive uncertainties and anxieties.

In conclusion, the cross-ethnic relationships which involve the business community have had a positive impact on the dynamism of social cohesion among the Malaysian business community in three levels, namely, individual, community, and institutional level. Malaysian environment with various ethnic groups allows all the ethnic groups to interact socially with groups of other ethnic groups and thus, build ethnic relationships among them. However, based on the findings, it revealed that there are numerous findings in terms of building ethnic relations even though the business community is living among the multi-ethnic society. The business community from various ethnic groups are reported to undertake the activities either in business or outside the business area then building relationships based on their ethnic groups. Therefore, the governments need to play an essential role in promoting ethnic relations among the business community with various programs to ensure they will interact socially with the business partners from other ethnic groups.

\section{REFERENCES}

Banton, M. 1991. The Race Relations Problematic. The British Journal of Sociology, Volume 41, Number 1, pp. 115-130.

Baker, W.E., 1990. Market networks and corporate behavior. American Journal of Sociology, Volume 96, Number 3, pp. 589-625.

Barth, F (pnyt). 1969. Ethnic Groups and Boundaries in the Social Organisation of Cultural Differences. London: Allen and Unwin.

Cox, O.C. 1948. Caste, Class and Race: A Study in Social Dynamic. New York: Montly Review Press.

Duchesneau and Gartner, 1988. A profile of new venture success and failure in an emerging industry. In. Kirchoff, B. A., (Ed.), Frontiers of entrepreneurial research. Wellesley, MA: Babson College. pp. $372-386$.

Eriksen, T.H. 2002. Ethnicity and Nationalism $2^{\text {nd }}$ Edition. London: Pluto Press.

Filpisan, M., Tomuletiu Adriana-Elena, Moraru, A., Stoica, M., Gorea,B. \& Solovastru, A. Procedia. Social and Behavioral Sciences, Volume 15, pp. 3263-3267. 
Hamdan, A. R., Ghafar, M.N. \& Ghani, A.A. (2010). Fostering inter-group contacts among multiracial students in UTM. Working paper presented in International Conference on Learner Diversity: ICELD. Bangi: UKM.

Hansen, E.L., 1995. Entrepreneurial networks and new organization growth. Entrepreneurship Theory and Practice, Volume 19, Number 4, pp. 7-19.

Government Transformation Programme: The Roadmap. (2010). Jabatan Perdana Menteri, Malaysia.

Gulati, 1995. Social structure and alliance formation pattern: A longitudinal analysis. Administrative Science Quarterly, Volume 40, Number 4, pp. 619-652.

Gulati, R. and G. Martin, 1999. Where do inter-organizational networks come from. American Journal of Sociology, Volume 104, Number 5, pp. 1439-1493.

Khairol Anuar Kamri. 2014. Impak Etnisiti, Tadbir Urus dan Etika Kerja Terhadap Kesepaduan Sosial Polis Diraja Malaysia. PhD Thesis, Institute oif Ethnic Studies, UKM.

Kasuma, S.A.A., 2017. Using facebook for English language learning: The differences among gender and ethnicity. Journal of Nusantara Studies, Volume 2, Number 1, pp. 177-193.

Lee, L., Carollee, H. \& Brandt, C. (2007). Merrill-Palmer Quarterly, Volume 53, Numeber 3, pp. 3.

Majzub, R. M., Hashim, S. \& Johannes, E. H. (2011). Procedia. Social and Behavioral Sciences, Volume 15, pp. 1573-1579.

Mansor Mohd Noor, Abdul Rahman Aziz \& Mohammad Ainuddin Iskandar Lee. 2006. Hubungan Etnik di Malaysia. Kuala Lumpur: Prentice Hall Malaysia.

Mohd Noor, M. (2012). Social differentiation and the thinning of ethnic boundaries. Public Lecture. UKM Publication: Bangi.

Molina, L.E. \& Wittig, M.A. (2006). Journal of Social Issues, Volume 62, Number 3, pp. 489-509.

Mustapha, R., Azman, N., Karim, F., Ahmad, A. R. \& Lubis M. A. (2009). Social Integration among Multiethnic Students at Selected Malaysian Universities in Penisular Malaysia: A Survey of Campus Social Climate. AJTLHE, Volume 1, Number 1, pp. 35-44.

Nier, J.A., Gaertner, S.L., Dovidio, J.F., Banker, B.S., Christine, M. W, \& Mary, C. R. (2001). Changing interracial evaluations and behavior: The effects of a common group identity. Group Processes \& Intergroup Relations, Volume 4, Number 4, pp. 299-316.

Pue Giok Hun (pnyt). 2013. Menyelusuri Cabaran Kepelbagaian: Pengalaman Malaysia Terkini. Ethnic Studies Paper 30. Bangi: Institut Kajian Etnik.

Shamsul Amri Baharuddin. (2008). Many ethnicities, many cultures, one nation: The Malaysian experience. Institute of Ethnic Studies, Universiti Kebangsaan Malaysia.

Shamsul Amri Baharuddin. 2011. Kesepaduan Dalam Pelbagaian: Perpaduan Di Malaysia Sebagai Work-In-Progess. Bangi: UKM.

Shamsul Amri Baharuddin. 2012. Modul Hubungan Etnik Edisi Kedua. Bangi: Institute of Ethnic Studies. Tropp, L. (2007). Social Psychology Quarterly, Volume 70, Number 1, pp. 70- 81.

Uzzi, B. 1996. The sources and consequences of embeddedness for the economic performance of organization: The network effect. American Sociological Review, Volume 61, Number 4, pp. 674-698. 